\title{
Cirrhosis in rats does not resolve in the long-term after induction by thioacetamide model $^{1}$
}

\author{
Rui, LA. ${ }^{*}$, Silva, EA. ${ }^{1}$, Silva, TC. ${ }^{2}$, Portela, TCL. ${ }^{3}$, Silva, AP. ${ }^{3}$, \\ Cogliati, B. ${ }^{2}$, Dagli, MLZ. ${ }^{2}$ and Hernandez-Blazquez, FJ. ${ }^{4}$
}

\begin{abstract}
${ }^{1}$ Department of Anatomy of Domestic and Wild Animals, School of Veterinary Medicine and Animal Science, University of São Paulo - USP, Av. Prof. Dr. Orlando Marques de Paiva, 87, CEP 05508-270, São Paulo, SP, Brazil

${ }^{2}$ Department of Pathology, School of Veterinary Medicine and Animal Science, University of São Paulo - USP, Av. Prof. Dr. Orlando Marques de Paiva, 87, CEP 05508-900, São Paulo, SP, Brazil

${ }^{3}$ Department of Cell Biology and Development, Institute of Biomedical Sciences, University of São Paulo - USP, Av. Prof. Lineu Prestes, 1524, CEP 05508-000, São Paulo, SP, Brazil

${ }^{4}$ Department of Surgery, School of Veterinary Medicine and Animal Science, University of São Paulo - USP, Av. Prof. Dr. Orlando Marques de Paiva, 87, CEP 05508-000, São Paulo, SP, Brazil

*E-mail: leandro.rui@usp.br
\end{abstract}

\begin{abstract}
Introductions: Hepatic cirrhosis is a final common pathway of all chronic liver diseases, characterized by deposit of fibrillar collagen and liver failure. Materials and Methods: In this experiment, hepatic cirrhosis was induced in 15 female Wistar rats by a 14-week period, with thioacetamide solution in a $200 \mathrm{mg} / \mathrm{kg}$ dosage, via intraperitoneal. Animals were submitted to liver biopsy, and euthanized after a 80-day post-induction period. Serum biochemical analysis was performed, in addition to histopathology by H.E., Picrosirius, Alcian Blue and P.A.S. stainings, following analysis of histological activity index and staging of fibrosis. Morphometric analysis of collagen on Picrosirius slides was also performed. Results: Mortality during experimental period was low (13.33\%), and after 80 -day period, liver function improved, cellular changes did not altered, and deposition of acidic mucopolysaccharides and glycogen were increased. Liver histological activity did not change significantly $(7.25 \pm 1.30$ to $6.41 \pm 1.32)$, but staging of fibrosis was altered $(3.91 \pm 0.76$ to $4.70 \pm 1.11)$. Interlobular collagen showed a significant decrease $(5.14 \pm 2.00$ to $4.00 \pm 1.20)$, while intralobular collagen was increased $(0.23 \pm 0.06$ to $0.36 \pm 0.08)$. Conclusions: These findings characterize thioacetamide as a safe experimental model for induction cirrhosis, which may be used for future therapy studies.
\end{abstract}

Keywords: cirrhosis, thioacetamide, Wistar rats, collagen, morphology.

\section{Introduction}

Hepatic fibrosis is a common response to liver injury (BRENNER, WATERBOER, CHOI et al., 2000), and its advance may result in cirrhosis, a final common pathway of all chronic liver diseases (FRIEDMAN, 2003), which is considered one of the 10 most common causes of death in the world and presents a poor prognosis, with a 5 -yearmortality rate of $85 \%$ in decompensated patients (STEWART and DAY, 2003; SCHUPPAN and AFDHAL, 2008).

Advance of fibrosis characterizes as a dynamic modification of the extracellular matrix, in which occurs a deposit of fibrillar collagen mediated by myofibroblasts, a cell phenotype derived from the hepatic stellate cells due to chronic injury (GABELE, BRENNER and RIPPE, 2003; IREDALE, 2007). Also, progressive disease may result in liver failure with portal hypertension and an increased risk of liver cancer (GINES, CARDENAS, ARROYO et al., 2004).

There are several recommended protocols for obtaining experimental models that characterize hepatic cirrhosis, through induction of liver injury by hepatotoxic drugs (LI, HUANG, WANG et al., 1990). Among them, one of the most used is carbon tetrachloride $\left(\mathrm{CCl}_{4}\right)$. However, there is a major drawback for the use of this drug: the variation of death of $30 \%$ during induction, besides the poor homogeneity and a low resemblance to human cirrhosis (LEE and GROSZMANN, 1999). Another known hepatotoxin is dimethylnitrosamine (DMN), a hepatotoxic, carcinogenic and mutagenic drug, and extensive fibrosis was attained at 3 weeks of application, being observed death of $42 \%$ (GEORGE, RAO, STERN et al., 2001). Also, a diet of L-amino acid with choline deficiency causes fibrosis at 16 weeks, with no related mortality (SAKAIDA, MATSUMURA, AKIYAMA et al., 1998).

An alternative drug for the induction of cirrhosis is the thioacetamide (TAA), a long-term hepatotoxin which chronic administration causes centrilobular necrosis and cirrhosis similar to the human disease, through a system of acetamide oxidation into thiaocetamide-S-oxide, and also by the hyperreactive thioacetamide-S-dioxide (ARIOSTO, RIGGIO, CANTAFORA et al., 1989; LALEMAN, VANDER ELST, ZEEGERS et al., 2006). Its half-life is relatively short (PORTER, GUDZINOWCZ and NEAL et al., 1979), presenting a known ability to cause acute and chronic toxicity and a safety between its necrogenic effects and liver

${ }^{1}$ This research was supported by the National Counsel of Technological and Scientific Development - CNPq and by the São Paulo Research Foundation - FAPESP. 
failure (MEHENDALE, 2005), characterizing this drug as a safe choice for chronic liver injury induction.

Orally administered thioacetamide was already verified by Laleman, Vander Elst, Zeegers et al. (2006), obtaining cirrhosis within 18 weeks and $16 \%$ death. The advantage of this route is the easy and atraumatic induction (LALEMAN, VANDER ELST, ZEEGERS et al., 2006). However, the induction of cirrhosis is heterogenous by this route, since another results presented variation from 3 to 7 months (PETERMANN, VOGL, SCHULZE et al., 1999; LI, BENJAMIN and ALEXANDER, 2002), due to different doses of ingestion of drinking water by the animals. Intraperitoneal injection of thioacetamide is used for induction of hepatic fibrosis for 8 weeks (XIE, WANG, WANG et al., 2012; HARN, LIN, HUNG et al., 2012), but no data was reported about maintenance of the disease after a post-induction period.

In this research, we chose intraperitoneal route to obtain an homogeneous induction of cirrhosis, since it is possible to measure the exact dose of drug injected in the animals. Thioacetamide was injected during 14 weeks, since a 8 -week period is known to induce fibrosis, and the aim of this study was to evaluate an advanced stage, of cirrhosis. After the induction, a 80-day post-induction period was chose to evaluate progression of the disease. After this period, cirrhosis still remained, according to the score of Ishak, Baptista, Bianchi et al. (1995). Thus, this experimental model contributed to the improvement of existing techniques of long-term induction of liver injury, as a model for future chronic liver injury treatment researches.

\section{Materials and Methods}

\subsection{Material}

In this study were used livers of fifteen (15) female rats (Rattus norvegicus), Wistar lineage, 2 months old and $191.5 \pm 9.4 \mathrm{~g}$ average body weight, from the biotherium of the Department of Pathology, School of Veterinary Medicine, University of São Paulo - USP. Animals were identified and arranged in boxes, into a group named $\mathrm{TAA}^{+80 \mathrm{~d}}$. This research was approved by the Committee of Bioethics of the School of Veterinary Medicine and Animal Science from the University of São Paulo, protocol number $1361 / 2008$.

\subsection{Methods}

\subsubsection{Management}

The animals were kept under controlled ambiental conditions of temperature $\left(22-24{ }^{\circ} \mathrm{C}\right)$ and luminosity (12-hour dark-light cycle), being given commercial food (Nuvital) and water ad libitum, and the weighing was carried out weekly. Thioacetamide (Sigma Aldrich, St. Louis, USA) was administered in $4 \%$ aqueous solution, $200 \mathrm{mg}$ / $\mathrm{kg}$ body weight, intraperitoneally, three times a week during 14 weeks. Each 24 days were added $10 \%$ of the solution, to avoid resistance to the drug.

Following up the 14 weeks of induction, animals were anesthetized with isofluorane (Isoforine ${ }^{\circledR}$, Cristalia, São Paulo, Brazil), and liver biopsy was performed to evaluate the establishment of cirrhosis as a comparative for the post-induction period. The group was then devoid of any applicability for 80 days, followed by euthanasia by excess of anesthesic. During biopsy (under anesthesia) and euthanasia, blood was collected by cardiac puncture for biochemical analysis.

\subsubsection{Experimental design}

After euthanasia of the rats, they were weighed, and celiotomy was performed for liver collection. The viscera (lungs, heart, kidneys, spleen, liver and full digestive tract) and the carcass were weighed separately.

The liver volume was calculated by immersion in water, being the volume equivalent to the displacement of water (GUERRA, TROTTA, ALOIA et al., 2010; COGLIATI, PEREIRA, DAGLI et al., 2010). Liver fragments were collected for histological analysis, being fixated in McDowell, for Prussian Blue; Metacarn, for Periodic Acid-Schiff (P.A.S.), hematoxylin-eosin (H.E.) and Alcin Blue; and Bouin, for Picrosirius staining.

Blood samples collected by cardiac puncture were transferred to microvials (MCI-150C, Homo-polymer, Oxygen Scientific) containing heparin (5.000 UI/0.25 $\mathrm{ml}$ heparin, Liquemine ${ }^{\circledR}$, Roche, São Paulo, Brazil), and then centrifuged (Microcentrifugue, SD 110VAC, Revan Cientific) for 5 minutes at $6.000 \mathrm{rpm}$ to obtain plasma.

\subsubsection{Serum biochemical analysis}

Quantitative measurement was made for the different indicators of liver function or damage: alanine aminotransferase (ALT), aspartate aminotransferase (AST), gamma-glutamyl transferase (GGT), alkaline phosphatase (ALPK), total bilirubin (TBIL), albumin (ALB), globulin (GLOB) and total protein (TP). All the enzimes were measured on specific slides (Idezz Vet Test ${ }^{\circledR}$, Idexx Laboratories, USA) by a blood chemistry analyzer (Vet Test 8008®, Idexx Laboratories, USA).

\subsubsection{Histopathology}

The cirrhotic livers of all animals were submitted to histopathological analysis under optical microscopy with aid of different techniques of specific staining for each evaluation.

Slides stained with HE evaluated the presence of oval cells, eosinophilic inclusions, mitotic figures, binucleated cells, steatosis, megalocytosis, vacuolation, nuclear damage, proliferation of ducts and the presence of apoptotic corpuscles. This quantification was standardized according to morphological features presented on liver cirrhosis. Also, was evaluated the presence of hemosiderin in slides submitted to Prussian blue staining; the presence of acid mucopolysaccharides, by Alcian Blue staining; and glycogen by staining with P.A.S.

These changes were semi-quantitatively assessed by determining score $0-3$. The score 0 corresponded to the absence of the change, $1=$ poor, $2=$ moderate and $3=$ intense. Following this grading, was determined the frequency of each intensity change.

The stage of liver cirrhosis and the histological activity index (HAI) were performed according to conventional criteria established by Knodell, Ishak, Black et al. (1981) and modified by Ishak, Baptista, Bianchi et al. (1995), where the lesions were classified according to the HAI (scores 1-18) 
and histological features of fibrosis, architectural disturbance and cirrhosis (scores 1-6). Analysis of HAI was performed using $\mathrm{HE}$ slides in 40, 100 and 400x magnifications (Olympus microscope PX21, Tokyo, Japan). The analysis for determining the stage of fibrosis was performed at $40 \mathrm{x}$ magnification, Picrosirius staining, which has specific affinity for collagen fibers.

\subsubsection{Morphometric analysis of collagen}

First, photographic documentation with the aid of an Olympus BX60 microscope (Axioscópio Zeiss ${ }^{\circledR}$ )attached to a camera (Axio Cam HRC Zeiss ${ }^{\circledR}$ ) was performed on slides stained with Picrosirius.

Then was performed the measurement of interlobular and intralobular collagen, quantified by the computerized system of image analysis Axio Vision 4.8 Zeiss (Carl Zeiss), under 200x magnification for interlobular collagen, and 600x magnification for intralobular collagen. Analyses were performed using the average values obtained by the sum of fields / animal. The values were expressed as percentage of each collagen location in relation to the total area.

\subsubsection{Statistical analysis}

Before performing statistical tests, was applied the Anderson-Darling normality test, with the aim of check the homoscedasticity of data (parametric or non-parametric).

In the intragroup analysis Student's t-test was performed for two paired and parametric samples and the Wilcoxon test for two paired and nonparametric samples. Were considered statistically significant the differences where $p<0.05$. Analyses were performed using the softwares Minitab® Release 14 Statistical Software (State College, PA, USA) and GraphPad InStat 3.06 (GraphPad Software Inc, San Diego, USA).

\section{Results}

The administration of TAA, associated to 80-day post-treatment period, caused no increase in mortality of animals

The group $\mathrm{TAA}^{+80 \mathrm{~d}}$ presented $13.33 \%$ mortality, corresponding to 2 animals, both deaths occurred at the end of cirrhosis induction.

Average weight of animals was altered during 80-day post-treatment period

Animals presented a slight decrease during period of cirrhosis induction. However, on 80-day post-treatment period, after thioacetamide injection was discontinued, the weight gain was exponential (Figure 1).

Biometric parameters, such as liver weight and volume, obtained after euthanasia of animals are presented in Table 1.

Liver function improved after 80-day post-induction period

Intragroup comparison was performed in the group $\mathrm{TAA}^{+80 \mathrm{~d}}$ in order to observe differences in cirrhosis biochemical parameters by the end of experimental period in relation to biopsy parameters. Thus, were compared data obtained with blood collected at biopsy (immediately after induction) and euthanasia. Biochemical profile improved at the end of experimental period in comparison to that observed at biopsy, the proteins ALB, TP and GLOB presented statistically significant increase. In addition, ALKP, AST and GGT decrease significantly in relation to induction period (Table 2).

Liver cellular changes did not altered after 80-day post-induction period

Intragroup comparison was performed in the group $\mathrm{TAA}^{+80 \mathrm{~d}}$ in order to observe differences in hepatic cellular changes by the end of experimental period. Thus were compared data obtained at biopsy (immediately after induction) and euthanasia (Figure 2). The only statistically different cellular change observed at the end of experimental

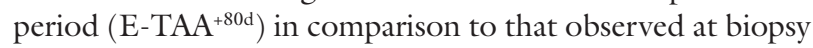
$\left(\mathrm{B}-\mathrm{TAA}^{+80 \mathrm{~d}}\right)$, was a reduction of nuclear lesions. Other parameters presented no statistical difference (Table 3 ).

The deposition of acidic mucopolysaccharides and glycogen increased after 80 -day post-induction period

Intragroup comparison was performed in the group

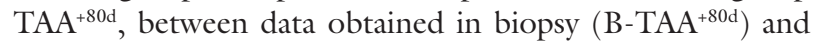
euthanasia $\left(\mathrm{E}-T A A^{+80 \mathrm{~d}}\right.$ ), and showed that deposition of acidic mucopolysaccharides increased during experimental period (Figure 3). Frequency of moderate deposition increased by $300 \%(7.69 \%$ to $30.77 \%)$, and intense deposition increased from 0.00 to $15.38 \%$ (Table 4 ).

According to Table 4, intensity of glycogen deposition increased during experimental period (Figure 4). Moderate depositon increased in $250.13 \%$ ( $15.38 \%$ to $53.85 \%)$, and intense deposition increase in $100.7 \%$ (15.38\% to $30.77 \%$ ).

Liver histological activity did not change after 80-day post-induction period

The histological activity index (HAI) obtained by analysis of necroinflammatory activity, classified according to criteria

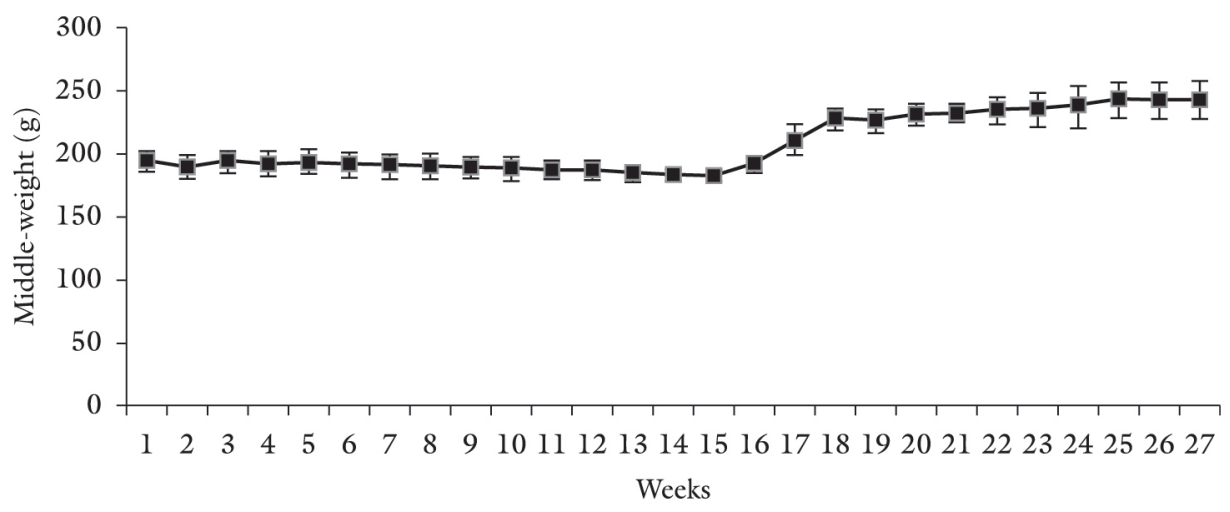

Figure 1. Average and standard deviation body weight evolution of animals subjected to induction of cirrhosis by TAA. 
of Knodell, Ishak, Black et al. (1981) and modified by Ishak, Baptista, Bianchi et al. (1995), demonstrated that tissue histological activity of animals did not change after 80 days. The comparison of data, obtained after analysis of liver tissue collected at biopsy $\mathrm{B}-\mathrm{TAA}^{+80 \mathrm{~d}}(7.25 \pm 1.30)$ and euthanasia

Table 1. Mean biometric parameters obtained after euthanasia of animals submitted to induction of cirrhosis by TAA.

\begin{tabular}{lc}
\hline \multicolumn{1}{c}{ Parameters } & E-TAA $^{+80 \mathrm{~d}}(\mathbf{n}=\mathbf{1 3})$ \\
\hline Body weight $(\mathrm{g})$ & $251.70 \pm 13.11$ \\
Carcass weight $(\mathrm{g})$ & $200.30 \pm 13.01$ \\
Liver weight $(\mathrm{g})$ & $8.70 \pm 1.10$ \\
Viscera weight $(\mathrm{g})$ & $45.45 \pm 4.41$ \\
Viscera/body weight index $(\%)$ & $18.40 \pm 1.20$ \\
Hepatic/corporal index $(\%)$ & $4.32 \pm 0.34$ \\
Hepatossomatic index $(\%)$ & $3.44 \pm 0.40$ \\
Liver volume $\left(\mathrm{cm}^{3}\right)$ & $8.00 \pm 1.00$ \\
Liver density $\left(\mathrm{cm}^{3} / \mathrm{g}\right)$ & $1.09 \pm 0.01$ \\
\hline
\end{tabular}

Table 2. Biochemical liver function parameters in the blood collected at biopsy and euthanasia of animals induced to cirrhosis by TAA.

\begin{tabular}{lcc}
\hline \multicolumn{1}{c}{ Parameters } & $\begin{array}{c}\text { B-TAA }^{+\mathbf{8 d}} \\
(\mathbf{n}=\mathbf{1 3})\end{array}$ & $\begin{array}{c}\text { E-TAA }^{+80 d} \\
(\mathbf{n}=\mathbf{1 3})\end{array}$ \\
\hline ALB $(\mathrm{g} / \mathrm{dL})$ & $2.10 \pm 0.24$ & $2.92 \pm 0.27^{\mathrm{a}}$ \\
$\mathrm{ALKP}(\mathrm{U} / \mathrm{L})$ & $280.92 \pm 20.70$ & $94.09 \pm 12.85^{\mathrm{a}}$ \\
$\mathrm{ALT}(\mathrm{U} / \mathrm{L})$ & $67.46 \pm 14.33$ & $78.23 \pm 15.99$ \\
$\mathrm{AST}(\mathrm{U} / \mathrm{L})$ & $194.85 \pm 17.59$ & $120.92 \pm 24.44^{\mathrm{a}}$ \\
$\mathrm{GGT}(\mathrm{U} / \mathrm{L})$ & $5.60 \pm 0.93$ & $0.15 \pm 0.25^{\mathrm{a}}$ \\
$\mathrm{TBIL}(\mathrm{mg} / \mathrm{dL})$ & $0.13 \pm 0.06$ & $0.12 \pm 0.04$ \\
$\mathrm{TP}(\mathrm{g} / \mathrm{dL})$ & $5.41 \pm 0.32$ & $6.85 \pm 0.30^{\mathrm{a}}$ \\
$\mathrm{GLOB}(\mathrm{g} / \mathrm{dL})$ & $3.32 \pm 0.23$ & $3.96 \pm 0.21^{\mathrm{a}}$ \\
\hline
\end{tabular}

${ }^{a}$ significant difference in relation to $\mathrm{B}-\mathrm{TAA}^{+80 \mathrm{~d}}, p<0,05$, Student t-test. ALB: albumine; ALKP: alkaline phosphatase; ALT: alanine transaminase; AST: aspartate transaminase; GGT: $\gamma$-glutamyltransferase; TBIL: total bilirubin; TP: total protein; GLOB: globuline.

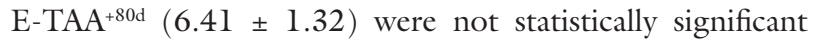
(Figure 5).

Staging of liver fibrosis/cirrhosis altered after 80-day post-induction period

Analysis of fibrosis graduation following criteria modified by Ishak, Baptista, Bianchi et al. (1995) performed in liver tissue collected at biopsy and euthanasia achieved, respectively, $3.91 \pm 0.76$ and $4.70 \pm 1.11$; significant differences were observed (Figure 3 and 6).

Proliferation of hepatic ducts was altered after 80-day post-induction period

Intragoup comparison $\left({\mathrm{B}-\mathrm{TAA}^{+80 \mathrm{~d}} \text { vs. E-TAA }}{ }^{+80 \mathrm{~d}}\right.$ ) showed that proliferation of ducts increased significantly over experimental period $(0.23 \pm 0.60$ to $1.62 \pm 1.20)$ (Figures 7 and 8).

Volumetric proportion of intralobular and interlobular collagen were altered after 80-day postinduction period

Intragoup comparison $\left(\mathrm{B}-\mathrm{TAA}^{+80 \mathrm{~d}}\right.$ vs. E-TAA $\left.{ }^{+80 \mathrm{~d}}\right)$ showed a significant decrease on volumetric proportion of intralobular

Table 3. Liver cellular changes observed in biopsy and euthanasia of animals induced to cirrhosis by TAA.

\begin{tabular}{lcc}
\hline \multicolumn{1}{c}{ Parameters } & $\begin{array}{c}\text { B-TAA }^{+80 d} \\
(\mathbf{n}=\mathbf{1 3})\end{array}$ & $\begin{array}{c}\text { E-TAA }^{+80 d} \\
(\mathbf{n}=13)\end{array}$ \\
\hline Oval cells & $1.62 \pm 0.65$ & $1.50 \pm 0.52$ \\
Eosinophilic inclusions & $1.31 \pm 0.50$ & $1.32 \pm 0.83$ \\
Mitotic figures & $1.10 \pm 0.50$ & $1.31 \pm 0.50$ \\
Binucleated cells & $1.23 \pm 0.44$ & $1.54 \pm 0.70$ \\
Steatosis & $0.15 \pm 0.40$ & $0.31 \pm 0.50$ \\
Hemosiderin & $1.40 \pm 0.65$ & $1.70 \pm 0.85$ \\
Megalocitosis & $1.92 \pm 0.64$ & $1.54 \pm 0.52$ \\
Vacuolization & $1.85 \pm 0.70$ & $1.62 \pm 0.90$ \\
Nuclear lesion & $1.70 \pm 0.50$ & $1.10 \pm 0.50$ \\
Apoptotic corpuscle & $1.40 \pm 0.80$ & $1.10 \pm 0.50$ \\
\hline
\end{tabular}

a significant difference in relation to $\mathrm{B}-\mathrm{TAA}^{+80 \mathrm{~d}}, p<0,05$, Wilcoxon test.
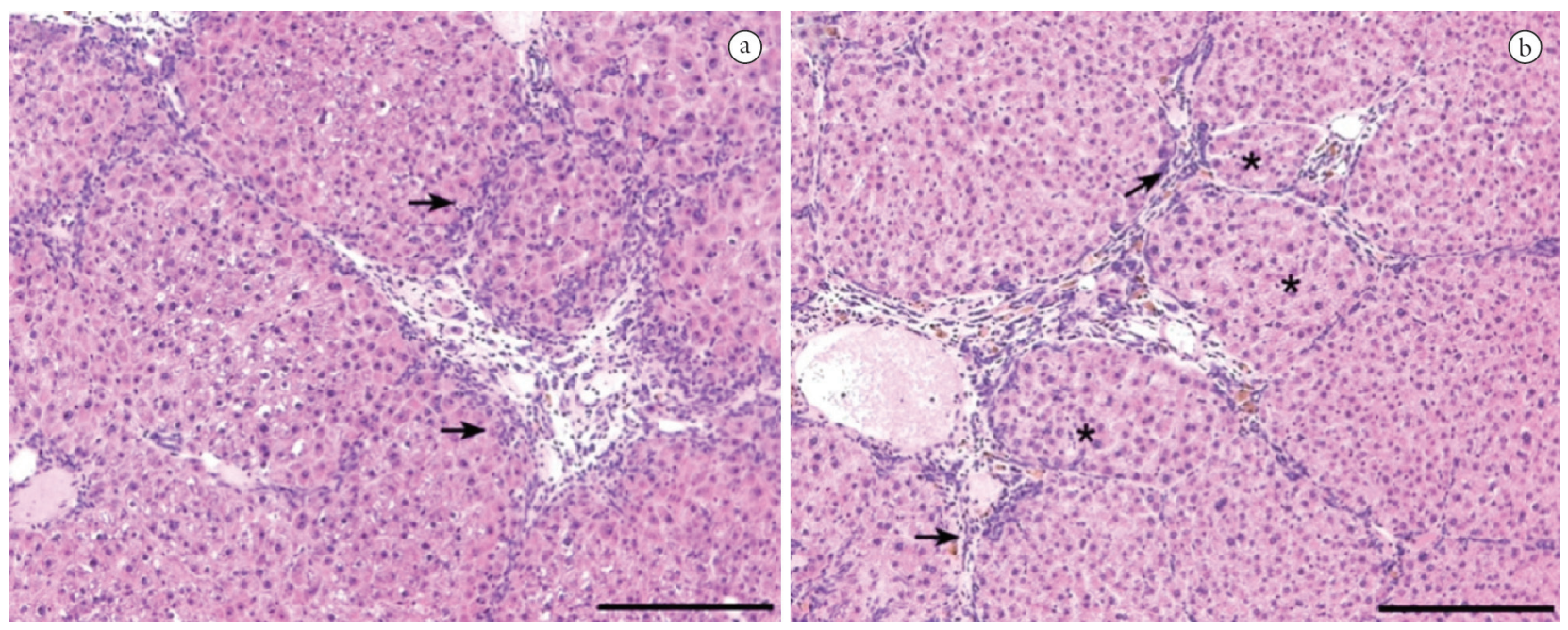

Figure 2. Photomicrography representing liver cirrhosis a) Material collected at biopsy, just after induction of cirrhosis. b) Material collected at euthanasia, 80 days after induction. Note the disarrangement of hepatic lobules. Arrows show great inflammatory infiltrate and collagen bridges; asterisks indicate regenerative nodules. (Bar $=200 \mu \mathrm{m})$. 

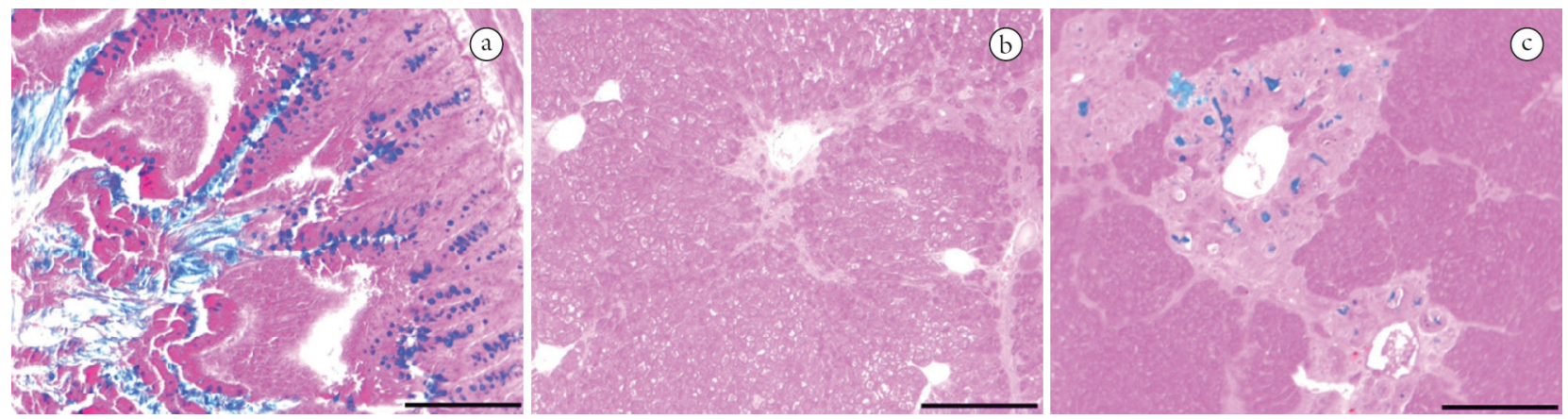

Figure 3. Photomicrography showing acid mucopolysaccharides. a) Rat small intestine used as positive control. b) Material collected at biopsy, just after induction of liver cirrhosis. c) Material collected at euthanasia, 80 days after induction of cirrhosis. Note the increased amount of acid mucopolysaccharides on liver collected at euthanasia. (Bar $=200 \mu \mathrm{m})$.

Table 4. Frequency of deposition of acidic mucopolysaccharides and glycogen observed in biopsy and euthanasia of animals induced to cirrhosis by TAA.

\begin{tabular}{cccccc}
\hline \multirow{2}{*}{ Parameters } & $\mathbf{n}=\mathbf{1 3}$ & \multicolumn{3}{c}{ Frequency (\%) } \\
\cline { 3 - 6 } & & Absent & Few & Moderate & Intense \\
\hline Mucopolysaccharides presence & B-TAA $^{+80 \mathrm{~d}}$ & 84.62 & 7.69 & 7.69 & 0.00 \\
Glycogen accumulation & E-TAA $^{+80 \mathrm{~d}}$ & 38.46 & 15.38 & 30.77 & 15.38 \\
& B-TAA $^{+80 \mathrm{~d}}$ & 0.00 & 69.23 & 15.38 & 15.38 \\
& E-TAA $^{+80 \mathrm{~d}}$ & 0.00 & 15.38 & 53.85 & 30.77 \\
\hline
\end{tabular}
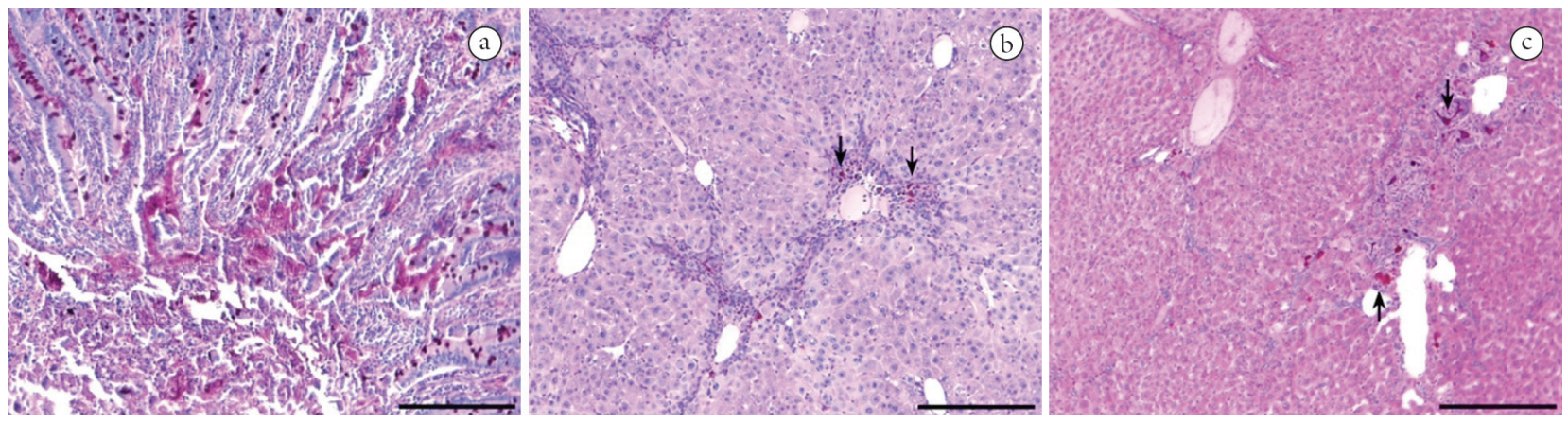

Figure 4. Photomicrography showing glycogen. a) Rat small intestine used as positive control. b) Material collected at biopsy. c) Material collected at euthanasia. Note the increased amount of glycogen on liver collected at euthanasia. $($ Bar $=200 \mu \mathrm{m})$.

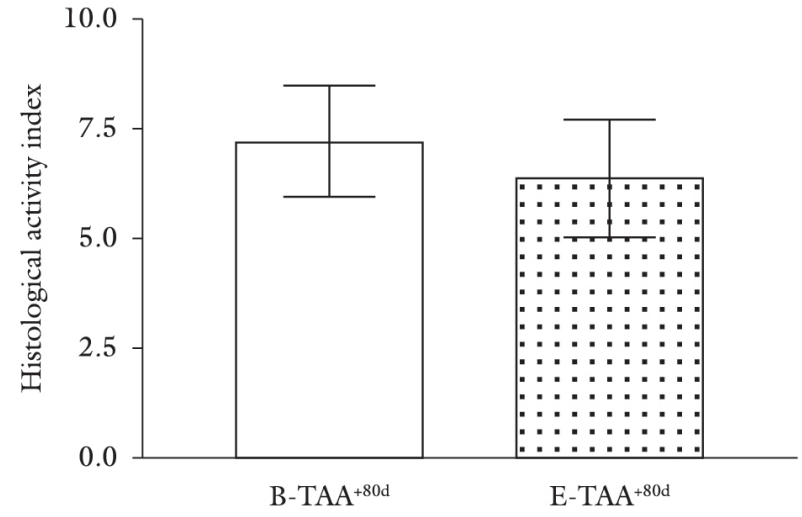

Figure 5. Staging of fibrosis, classified according to criteria of Ishak, Baptista, Bianchi et al. (1995), on liver tissue obtained

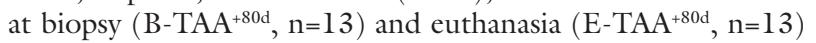
of animals induced to cirrhosis by TAA. Differences were not significant, $\mathrm{p}>0,05$, Wilcoxon test.

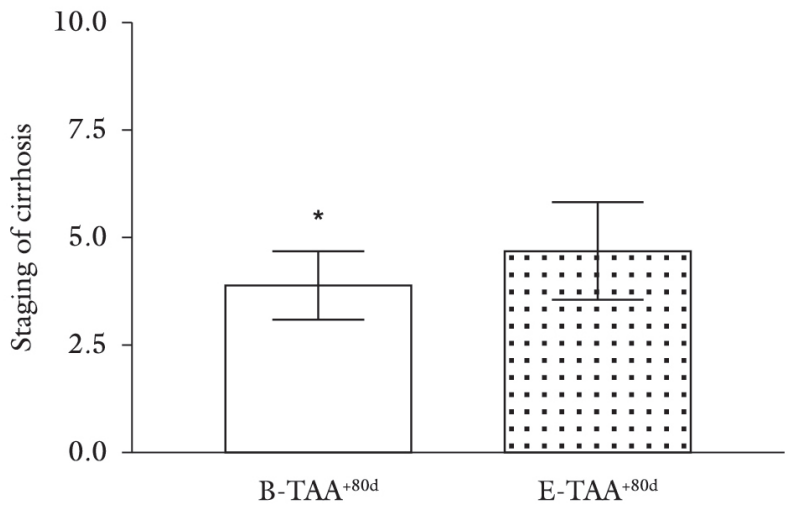

Figure 6. Staging of fibrosis, classified according to criteria of Ishak, Baptista, Bianchi et al. (1995), on hepatic tissue obtained

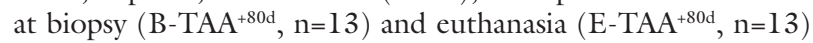
of animals induced to cirrhosis by TAA. *Significant differences, $p<0,05$, Wilcoxon test. 
collagen and an increase on volumetric proportion of interlobular collagen (Table 5, Figures 9 and 10).

\section{Discussion}

Thioacetamide is a long-term hepatotoxin which causes centrilobular necrosis and cirrhosis due to oxidation mechanisms of hyper-reactive compounds (LALEMAN, VANDER ELST, ZEEGERS et al., 2006). In this experimental model, we successfully achieved the cirrhosis stage in a period of 14 weeks by intraperitoneal injection of thioacetamide. It has been reported that orally administered thioacetamide achieved cirrhosis in both a 18 -week period

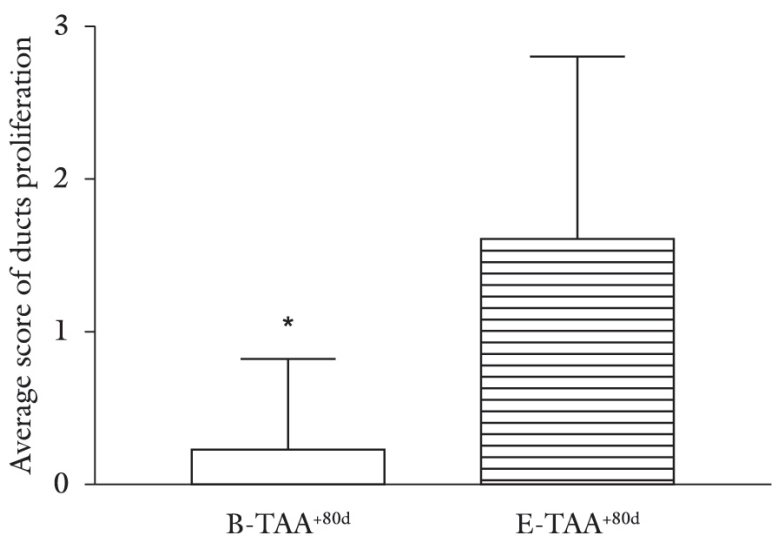

Figure 7. Proliferation of ducts observed in biopsy $\left(\mathrm{B}^{-T A A}{ }^{+80 \mathrm{~d}}\right.$,

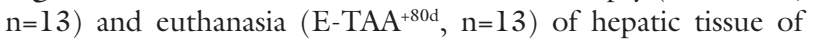
animals induced to cirrhosis by TAA. *Significant differences, $\mathrm{p}<0,05$, Wilcoxon test.
(LALEMAN, VANDER ELST, ZEEGERS et al., 2006) and a 29-week period (GU, ZHAO, REN et al., 2011). However, difference in experimental periods by oral route characterizes heterogeneous induction of disease, since ingestion of drinking water may differ between animals. Intraperitoneal induction, on the other hand, allow exact measure of drug being administered.

In this research, a low mortality of $13,33 \%$ (2 animals) was presented, characterizing thioacetamide as a safe drug for induction of cirrhosis. Guerra, Trotta, Aloia et al. (2010) presented a $4 \%$ mortality index by this route, and orally administered thioacetamide caused death of 0 to $4 \%$ of animals, respectively (LALEMAN, VANDER ELST, ZEEGERS et al., 2006; GU, ZHAO, REN et al., 2011). Experimental models of cirrhosis by $\mathrm{CCl}_{4}$, however, may lead to 20-50\% mortality (LEE and GROSZMANN, 1999; GEERTS, VANHEULE, PRAET et al., 2008). Therefore, thioacetamide is highly recommended for experimental induction of cirrhosis, due to its great safety in comparison to other drugs.

Weights during the experimental period showed a slight decline in body condition of animals at the end of cirrhosis induction, indicating that probably there was metabolic impairment that led to this phenomenon. In the 80 days post-induction, there was exponential weight gain, exceeding the initial weight, possibly due to the lack of hepatotoxic drugs action and excessive stress of animals management. Guerra, Trotta, Aloia et al. (2010) also obtained similar results during experimental period.

Biochemical markers of liver injury have a function of evaluating liver and biliary system conditions (GOMES, PARRA, FRANCO et al., 2008). On biochemical analysis was found that plasma levels of ALT, AST, GGT and ALPK
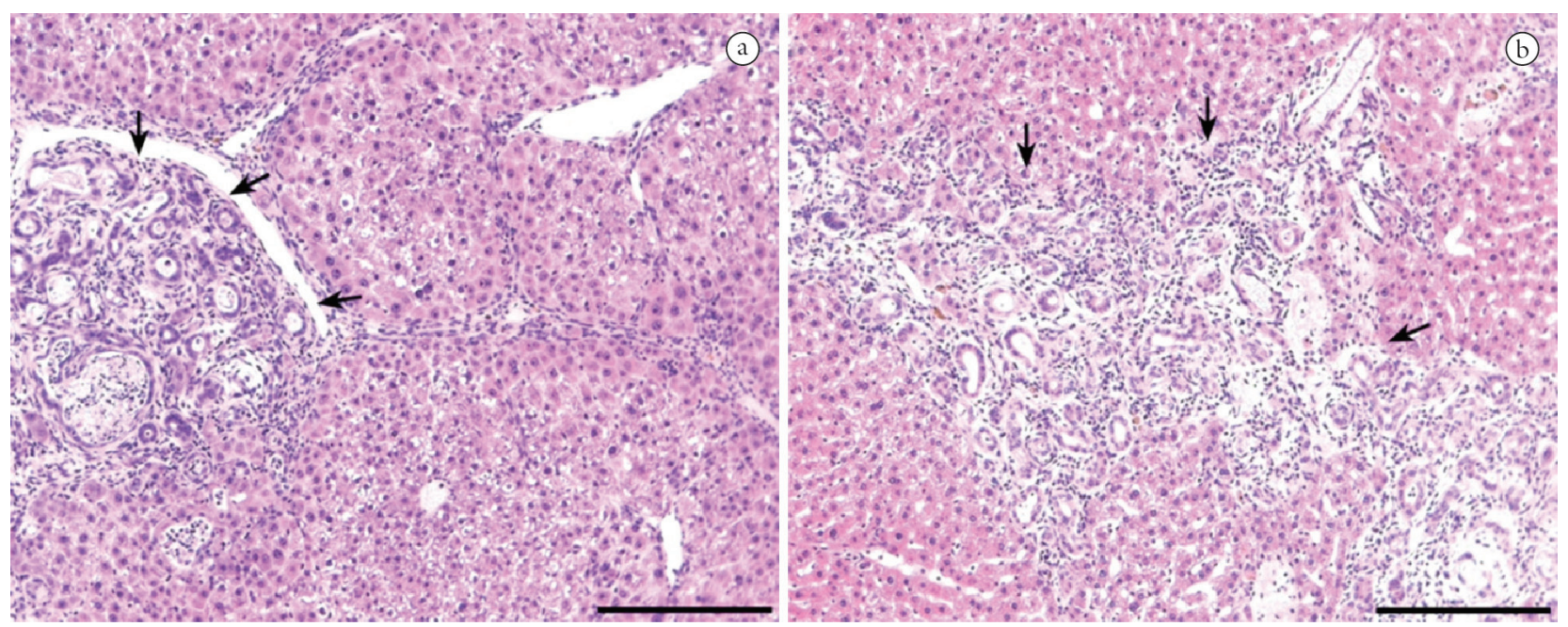

Figure 8. Arrows point to duct proliferation. Note the increased amount of proliferated ducts in liver collected at euthanasia (b) when compared to liver collected at biopsy. (Bar $=200 \mu \mathrm{m})$.

Table 5. Volumetric proportion of interlobular and intralobular collagen observed in biopsy and euthanasia of animals induced to cirrhosis by TAA.

\begin{tabular}{lccr}
\hline \multicolumn{1}{c}{ Type of collagen } & B-TAA $^{+80 \mathrm{~d}}(\mathbf{n}=\mathbf{1 3})$ & E-TAA $^{+80 \mathrm{~d}}(\mathbf{n}=\mathbf{1 3})$ & Increase or decrease in \% \\
\hline Interlobular & $5.14 \pm 2.00^{\mathrm{a}}$ & $4.00 \pm 1.20$ & $\downarrow 22.15$ \\
Intralobular & $0.23 \pm 0.06^{\mathrm{a}}$ & $0.36 \pm 0.08$ & $\uparrow 56.22$ \\
\hline
\end{tabular}

${ }^{a}$ significant difference in relation to $\mathrm{B}-\mathrm{TAA}^{+80 \mathrm{~d}}, p<0,05$, Student t-test. 

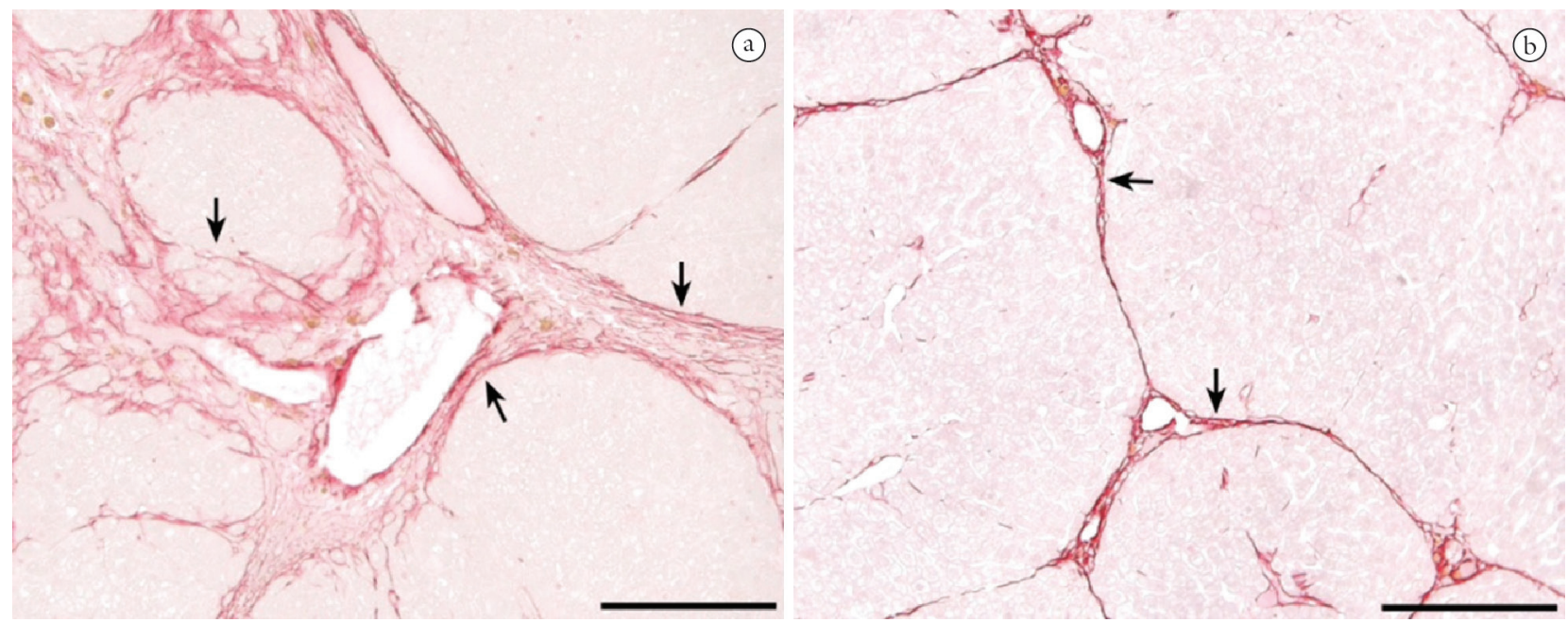

Figure 9. Photomicrography representing interlobular collagen. There was significative decrease on deposition of interlobular collagen in liver collected at euthanasia, 80 days after induction of cirrhosis (b) when compared to material collected at biopsy, just after induction of cirrhosis $(\mathrm{a})$. ( $\mathrm{Bar}=200 \mu \mathrm{m})$.
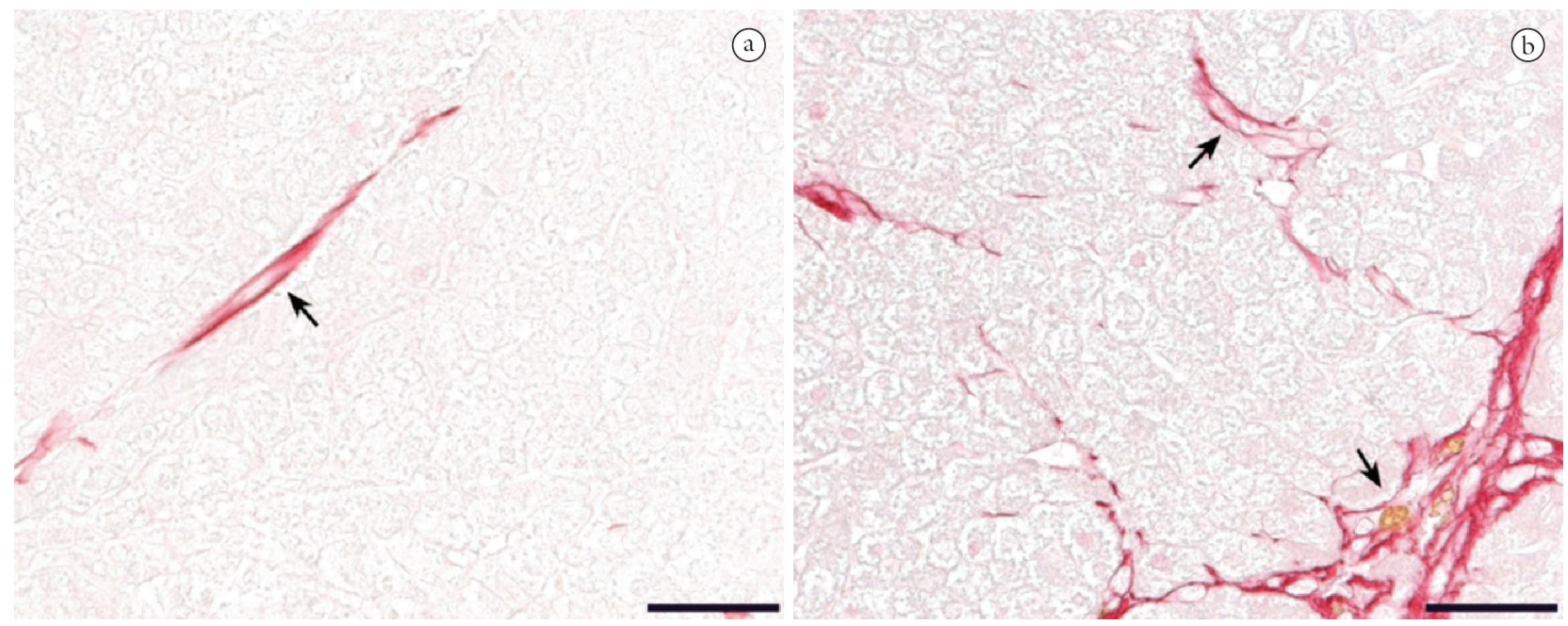

Figure 10. Photomicrography representing intralobular collagen. There was significative increase on deposition of intralobular collagen in liver collected at euthanasia (b) when compared to material collected at biopsy, just after induction of cirrhosis (a). $($ Bar $=50 \mu \mathrm{m})$.

were increased at the end of induction of cirrhosis, as well as low values of albumin, globulins and total protein, indicating there was probably impairment of synthesis capacity of the liver, responsible for producing the majority of the proteins present in blood plasma (LALEMAN, VANDER ELST, ZEEGERS et al., 2006; IIMURO, NISHIO, MORIMOTO et al., 2003). Reduction of albumin usually occurs only when there is more than $70 \%$ of loss in the liver function, with reduction of protein synthesis and increased capillary permeability. High levels of ALT and AST, hepatocyte outflow enzymes, indicate cell damage (KAIBORI, KWON, NAKAGAWA et al., 1997), releasing these enzymes into the blood. Also, animals presented increased levels of GGT and ALPK, which are indicative of cholestasis, caused by characteristics of fibrosis and cirrhosis of regenerative nodules that affect the biliary ducts, as well as other components of the portal system, characterizing portal hypertension.

Biochemical markers at euthanasia, however, presented decrease in GGT, ALT and AST levels in relation to the end of induction, and plasma protein levels showed a significant increase, indicating liver managed to improve its function, even though cirrhosis was maintained, considering that there were no significant differences in histopathology after the 80 days rest period. ALT values showed even higher than at the biopsy samples. However, this enzyme may remain high even some time after the resolution of the initial disease, not necessarily indicating that there was progression of the lesion.

Moderate deposit of glycogen in the liver increased by $250.13 \%$, and intense deposit by $100.7 \%$ in euthanasia, which is associated with high levels of ALT, since this enzyme catalyses the interconversion of the amino group of alanine 
to *-ketoglutarate, forming pyruvate, and thus playing an important role in the gluconeogenesis and the metabolism of liver amino acids (SCHINDHELM, DIAMANT, DEKKER et al., 2006).

Acid mucopolysaccharides also presented a moderate deposition increase by $300 \%$ and intense deposition by $15.38 \%$. This compound is present in injured liver, and is well documented that the administration of TAA for 14 weeks by oral route promotes intense biliary ducts proliferation and cholangiocarcinoma (AL-BADER, MATHEW, ABUL et al., 2000). Prolonged treatment with this drug leads to dysplasia of the biliary epithelium with mucin production similar to that observed in human cholangiocarcinoma $(\mathrm{YEH}$, MAITRA, LEE et al., 2004; ZEN, SASAKI, FUJII et al., 2006), explaining the increase of these mucopolyssacharides during experimental period.

Histological activity index (HAI) and staging of liver disease were classified according to criteria of Knodell, Ishak, Black et al. (1981) and modified by Ishak, Baptista, Bianchi et al. (1995). HAI value was high and showed no significant difference between biopsy and euthanasia. Staging also characterized successful achievement of cirrhosis stage, which even worsened after post-induction period. These findings support that this experimental model was efficient for induction of cirrhosis and its maintenance during a long period.

Hepatic stellate cells (HSC) are mesenchymal cells of the liver, which become activated upon fibrogenic stimulus, increasing synthesis of type I collagen. (JIANG and STEFANOVIC, 2008). As excessive accumulation of these extracellular matrix proteins occur, liver fibrosis and cirrhosis take place, by modifying morphology and vascularization of the organ, and therefore its function. (BRENNER, VELOZ, JAENISCH et al., 1993). We measured intralobular and interlobular hepatic collagen. There was an increase of intralobular collagen in euthanasia, which caused a sinusoid capillarization and resulted in damage to morphology, and possibly the function of the organ. Interlobular collagen, however, showed a decrease, which can be explained by a remodeling of the conformation of the organ and by a lower vascular permeability after injury interruption, thereby reducing the deposit of fibers.

All findings mentioned above were sucessfully managed by the administration of TAA for a period of 14 weeks, and remained after a 80-day post-induction period, characterizing a safe experimental model for induction of cirrhosis, which may be used for future therapy studies. We also suggest immunohistochemical and molecular studies of hepatic stellate cells during post-induction periods, so mechanisms involved on collagen synthesis may be correlated to this experimental model.

\section{References}

AL-BADER, A., MATHEW, TC., ABUL, H., AL-SAYER, H., SINGAL, PK. and DASHTI, HM. Cholangiocarcinoma and liver cirrhosis in relation to changes due to thioacetamide. Molecular and Cellular Biochemistry, 2000, vol. 208, n. 1-2, p. 1-10. PMid:10939622. http://dx.doi.org/10.1023/A:1007082515548
ARIOSTO, F., RigGIO, O., CANTAFORA, A., COLUCCI, S., GAUDIO, E. and MECHELLI, C. Carbon tetrachloride-induced experimental cirrhosis in the rat: a reappraisal of the model. European Surgical Research, 1989, vol. 21, p. 280-286. PMid:2627982. http://dx.doi.org/10.1159/000129038

BRENNER, DA., VELOZ, L., JAENISCH, R. and ALCORN, JM. Stimulation of the collagen alpha 1 (I) endogenous gene and transgene in carbon tetrachloride-induced hepatic fibrosis. Hepatology, 1993, vol. 17, p. 287-292. PMid:8428727.

BRENNER, DA., WATERBOER, T., CHOI, SK., LINDQUIST, JN., STEFANOVIC, B., BURCHARDT, E, YAMAUCHI, M., GILLAN, A. and RIPPE, RA. New aspects of hepatic fibrosis. Journal of Hepatology, 2000, vol. 32 , suppl. 1, p. 32-38.

COGLIATI, B., PEREIRA, HM., DAGLI, MLZ., PARRA, OM., SILVA, JR. and HERNANDEZ-BLAZQUEZ, FJ. Hepatotrophic factors reduce hepatic fibrosis in rats. Arquivos de Gastroenterologia, 2010, vol. 47, n. 1, p. 79-85. PMid:20520980.

FRIEDMAN, SL. Liver fibrosis - from bench to bedside. Journal of Hepatology, 2003, vol. 38, suppl. 1, p. S38-S53. http://dx.doi. org/10.1016/S0168-8278(02)00429-4

GABELE, E., BRENNER, DA. and RIPPE, RA. Liver fibrosis: signals leading to the amplification of the fibrogenic hepatic stellate cell. Frontiers in Bioscience, 2003, vol. 8, p. D69-D77. PMid:12456323. http://dx.doi.org/10.2741/887

GEERTS, AM., VANHEUle, E., PRAET, M., VLIERBERGHE, HV., VOS, M. and COLLE, I. Comparison of three research models of portal hypertension in mice: macroscopic, histological and portal pressure evaluation. International Journal of Experimental Pathology, 2008, vol. 89, n. 4, p. 251-263. PMid:18715470 PMCid:PMC2525776. http://dx.doi.org/10.1111/j.13652613.2008.00597.x

GEORGE, J., RAO, KR., STERN, R. and CHANDRAKASAN, G. Dimethylnitrosamine-induced liver injury in rats: the early deposition of collagen. Toxicology, 2001, vol. 156, p. 129-138. http://dx.doi.org/10.1016/S0300-483X(00)00352-8

GINES, P., CARDENAS, A., ARROYO, V. and RODES, J. Management of cirrhosis and ascites. The New England Journal of Medicine, 2004, vol. 350, p. 1646-1654. PMid:15084697. http:// dx.doi.org/10.1056/NEJMra035021

GOMES, A., PARRA, BS., FRANCO, FO., BASILE, L., JOSÉ, LT. and ROMERO, VL. Exame da função hepática na medicina veterinária. Revista Cientifica Eletrônica de Medicina Veterinária, 2008, vol. 6, n. 11, p. 1-7.

GU, K., ZHAO, JD., REN, ZG., MA, NY., LAI, ST., WANG, J., LIU, J. and JIANG, GL. A natural process of cirrhosis resolution and deceleration of liver regeneration after thioacetamide withdrawal in a rat model. Molecular Biology Reports, 2011, vol. 38, p. 1687 1696. PMid:20931291. http://dx.doi.org/10.1007/s11033-0100281-1

GUERRA, RR., TROTTA, MR., ALOIA, TP., DAGLI, ML., HERNANDEZ-BLAZQUEZ, FJ. A novel chronic cirrhosis TAA-induced model in rats. Brazilian Journal of Veterinary Pathology, 2010, vol. 3, n. 1, p. 9-16.

HARN, HJ., LIN, SZ., HUNG, SH., SUBEQ, YM., LI, YS., SYU, WS., DING, DC., LEE, RP., HSIEH, DK., LIN, PC. and CHIOU, TW. Adipose-derived stem cells can abrogate chemicalinduced liver fibrosis and facilitate recovery of liver function. Cell Transplantation, 2012, vol. 21, p. 2753-2764. PMid:22776464. http://dx.doi.org/10.3727/096368912X652959 
IIMURO, Y., NISHIO, T., MORIMOTO, T., NITTA, T., STEFANOVIC, B., CHOI, SK., BRENNER, DA. and YAMAOKA, Y. Delivery of matrix metalloproteinase- 1 attenuates established liver fibrosis in the rat. Gastroenterology, 2003, vol. 124, n. 2, p. 445-458. PMid:12557150. http://dx.doi.org/10.1053/gast.2003.50063

IREDALE, JP. Models of liver fibrosis: exploring the dynamic nature of inflammation and repair in a solid organ. The Journal of Clinical Investigation, 2007, vol. 117, n. 3, p. 539-548. PMid:17332881 PMCid:PMC1804370. http://dx.doi.org/10.1172/JCI30542

ISHAK, K., BAPTISTA, A., BIANCHI, L., CALLEA, F., GROOTE, J., GUDAT, F., DENK, H., DESMET, V., KORB, G., MACSWEEN, RNM., PHILlIPS, MJ., PORTMANN, BG., POULSEN, H., SCHEUER, PJ., SCHMID, M. and THALER, $\mathrm{H}$. Histological grading and staging of chronic hepatitis. Journal of Hepatology, 1995, vol. 22, p. 696-699. http://dx.doi. org/10.1016/0168-8278(95)80226-6

JIANG, F. and STEFANOVIC, B. Homeobox gene Prxl is expressed in activated hepatic stellate cells and transactivates collagen al(I) promoter. Experimental Biology and Medicine, 2008, vol. 233, p. 286-296. PMid:18296734. http://dx.doi.org/10.3181/0707RM-177

KAIBORI, M., KWON, AH., NAKAGAWA, M., WEI, T., UETSUJI, S., KAMIYAMA, Y., OKUMURA, T. and KITAMURA, $\mathrm{N}$. Stimulation of liver regeneration and function after partial hepatectomy in cirrhotic rats by continuous infusion of recombinant human hepatocyte growth factor. Journal of Hepatology, 1997, vol. 27, n. 2, p 381-390. http://dx.doi.org/10.1016/S01688278(97)80185-7

KNODELL, RG., ISHAK, KG., BLACK, WC., CHEN, TS., CRAIG, R., KAPLOWITZ, N., KIERNAN, TW. and WOLLMAN, J. Formulation and application of a numerical scoring system for assessing histological activity in asymptomatic chronic active hepatitis. Hepatology, 1981, vol. 1, n. 5, p. 431-435. PMid:7308988. http://dx.doi.org/10.1002/hep.1840010511

LALEMAN, W., VANDER ELST, I., ZEEGERS, M., SERVAES, R., LIBBRECHT, L., ROSKAMS, T., FEVERY, J., NEVENS, F. A stable model of cirrhotic portal hypertension in rat: thioacetamide revisited. European Journal of Clinical Investigation, 2006, vol. 36, n. 4, p. 242-249. PMid:16620286. http://dx.doi.org/10.1111/ j.1365-2362.2006.01620.x

LEE, FY. and GROSZMANN, RJ. Experimental models in the investigation of portal hypertension. Ascites and Renal Dysfunction in Liver Disease: Pathogenesis, Diagnosis, and Treatment, 1999, vol. 1, p. 365-78.

LI, X., BENJAMIN, IS. and ALEXANDER, B. Reproducible production of thioacetamide-induced macronodular cirrhosis in the rat with no mortality. Journal of Hepatology, 2002, vol. 36, p. 488493. http://dx.doi.org/10.1016/S0168-8278(02)00011-9

LI, XN., HUANG, CT., WANG, XH., LENG, XS., DU, RY. and CHEN, YF. Changes of blood humoral substances in experimental cirrhosis and their effects on portal hemodynamics. Chinese Medicine Journal, 1990, vol. 103, p. 970-977.

MEHENDALE, HM. Tissue repair: an important determinant of final outcome of toxicantinduced injury. Toxicologic Pathology, 2005, vol. 33, p. 1-10. PMid:15805049.
PETERMANN, H., VOGL, S., SCHUlze, E., DARGAL, R. Chronic liver injury alters basal and stimulated nitrix oxide production and ${ }^{3} \mathrm{H}$-thymidine incorporation in cultured sinusoidal endothelial cells from rats. Journal of Hepatology, 1999, vol. 31, n. 2, p. 284292. http://dx.doi.org/10.1016/S0168-8278(99)80226-8

PORTER, WR., GUDZINOWCZ, MJ. and NEAL, RA. Thioacetamide-induced hepatic necrosis. II. Pharmacokinetics of thioacetamide and thioacetamide-S-oxide in the rat. Journal of Pharmacologytal and Experimental Therapeutics, 1979, vol. 208, p. 386-391. PMid:430359.

SAKAIDA, I., MATSUMURA, Y., AKIYAMA, S., HAYASHI, K., ISHIGE, A. and OKITA, K. Herbal medicine Sho-saiko-to (TJ9) prevents liver fibrosis and enzyme-altered lesions in rat liver cirrhosis induced by a choline-deficient L-amino acid-defined diet. Journal of Hepatology, 1998, vol. 28, p. 298-306. http://dx.doi. org/10.1016/0168-8278(88)80017-5

SCHINDHELM, RK., DIAMANT, M., DEKKER, JM., TUSHUIZEN, ME., TEERLINK, T. and HEINE, RJ. Alanine aminotransferase as a marker of non-alcoholic fatty liver disease in relation to type 2 diabetes mellitus and cardiovascular disease. Diabetes/Metabolism Research and Reviews, 2006, vol. 22, n. 6, p. 437-443. PMid:16832839. http://dx.doi.org/10.1002/ dmrr.666

SCHUPPAN, D. and AFDHAL, NH. Liver Cirrhosis. Lancet, 2008, vol. 371, p. 838-851. http://dx.doi.org/10.1016/S01406736(08)60383-9

STEWART, SF. and DAY, CP. The management of alcoholic liver disease. Journal of Hepatology, 2003, vol. 38, suppl. 1, p. 2-13. http://dx.doi.org/10.1016/S0168-8278(02)00427-0

XIE, Y., WANG, G., WANG, H., YAO, X., JIANG, S., KANG, A., ZHOU, F., XIE, T. and HAO, H. Cytochrome p450 dysregulations in thioacetamide-induced liver cirrhosis in rats and the counteracting effects of hepatoprotective agents. Drug Metabolism and Disposition, 2012, vol. 40, n. 4, p. 796-802. PMid:22266841. http://dx.doi.org/10.1124/dmd.111.043539

YEH, C., MAITRA, A., LEE, K., JAN, Y. and CHEN, M. Thioacetamide-induced intestinal-type cholangiocarcinoma in rat: an animal model recapitulating the multi-stage progression of human cholangiocarcinoma. Carcinogenesis, 2004, vol. 25, n. 4, p. 631-636. PMid:14656942. http://dx.doi.org/10.1093/ carcin/bgh037

ZEN, Y., SASAKI, M., FUJII, T., CHEN, T., CHEN, M., YEH, T., JAN, Y., HUANG, S., NIMURA, Y. and NAKANUMA, Y. Different expression patterns of mucin core proteins and cytokeratins during intrahepatic cholangiocarcinogenesis from biliary intraepithelial neoplasia and intraductal papillary neoplasm of the bile duct--an immunohistochemical study of 110 cases of hepatolithiasis. Journal of Hepatology, 2006, vol. 44, n. 2, p. 350-358. PMid:16360234. http://dx.doi.org/10.1016/j.jhep.2005.09.025

Received October 1, 2013 Accepted April 9, 2014 